\title{
Hula Hoop Dance to Stimulate Child's Characters in Kindergarten
}

\section{Sri Sumarni ${ }^{1, *}$ Windi Dwi Andika ${ }^{1,}$ Umi Chotimah $^{1,}$ Ruri Tria Astika ${ }^{2}$}

\author{
${ }^{I}$ Teacher Training and Education, Sriwijaya University, Inderalaya 30662 , Indonesia \\ ${ }^{2}$ The State University of Jakarta, Jakarta 13220, Indonesia \\ ${ }^{*}$ Corresponding author.Email: sri_sumarni@fkip.unsri.ac.id
}

\begin{abstract}
Character development develops optimally at an early age. Stimulation of children's characters can be done with various kindergarten activities, the Hula Hoop Dance. However, the reality is only through habituation activities. This research aims to discover more about kindergarten children's characters developed through Hula Hoop Dance activities from various library studies such as journals. Based on the library study, the findings found that 13 characters can be developed from Hula Hoop Dance activities, among others: religious, honest, brave, persistent, confident, healthy living, polite, patient, orderly, disciplined, tolerance, collaboration, cooperation. Stimulation of children's characters through Hula Hoop Dance activities is recommended to be implemented in Kindergarten.
\end{abstract}

Keywords: Hula hoop dance, Early childhood characters, child stimulation

\section{INTRODUCTION}

Education character is essential for students. Character is an essential aspect of shaping a person's personality. Understanding the importance of character education for the nation's children, the government requires character education in each learning curriculum. The character was building at the level of education, especially early childhood education. Quality characters need to be shaped and built from early childhood. Early childhood education is education for children zero until eight years who were at a sensitive period. The period has a positive effect on character building. Children can filter out good and bad information. Then they can distinguish between good and bad attitudes. Suppose children have given appropriate stimulation so that the impact will showing all development aspects. Hence the teacher stimulates children with active and fun activities to get many chances to explore their world.

In early childhood, children experience fast growth and development. Children absorb knowledge through what they looked, heard, tasted, touched, and smelled. Hence appropriate stimulation from the teacher is key to success in the future.

The role of teacher needed and parents as the leading role in their children's stimulations. Because parents have many chances and times to interact with their children, they can communicate and collaborate to stimulate children with the appropriate activity.

So far, character-building has only been developed through habit activity in the school and home. The reality of what happened is against the fact of the study.
It is a scientific fact that character building is developed by habits and active and enjoyable activities such as music and movement activities, dance, games, etc. This gap raises research problems. What kinds of characters can be developed by dancing hula hoop?

Preliminary research Hula Hoop dance was developing affective aspects development of children in Kindergarten [1]. Other research has shown that playing hula hoop can stimulate development aspects [2]. Other studies have shown that early childhood gross motor skills and a positive effect can be improved by playing hula hoops [3]. The three studies above can be a solution to research problems. The state of the research's art is hula hoop as a movement activity that developed children's character.

However, an analysis of literature studies is needed on what kinds of character can be developed from dancing hula hoop. Researchers focus on analyzing one by one the characters evolve from the various movements of the hula hoop dancing.

The research novelty will find two kinds of characters that can develop from hula hoop dancing. They are individual and social characters. Each kind of character is divided into many characters form. Then each form of character will analyze based on relevant research to produce valid research results. The research topic has not been studied much about hula hoop dance because previous studies emphasize playing hula hoop. The research focus is unique because it will identify and analyze kinds of characters from hula hoop dancing. The study's objectives will delve around children's character from dancing hula hoop with the research library method. 


\section{METHOD}

This qualitative research method is library research using journals as the main object. This method provides a clear, objective, systematic, analytical, and critical description and explanation of the character values developed through the Hula Hoop Dance activities. This qualitative research method is library research using journals as the main object. This method provides a clear, objective, systematic, analytical, and critical description and explanation of the character values developed through the Hula Hoop Dance activities. Sources of data in research are primary and secondary sources whose substance is philosophical and theoretical processing actions, without any empirical tests. Data collection is done by collecting books and journals about character values and then presenting it for analysis [4].

Primary source: Journal of Atlantis Press: Journal of Hula Hoop Dance in Early Childhood. At the same time, the secondary sources include (1) SPORTIF Journal: Learning Research Journal entitled "Hula Hoop Game: Its Use and Implication for Physical Fitness." (2) Potential Scientific Journal: Improving Children's Gross Motor Ability through Playing with Hula Hoop Media in Children of Group B PAUD Al-Syafaqoh, Rejang Regency. (3) "The Dynamics of an Elastic Hopping Hoop" (4)

The data analysis technique used is content analysis [5]. Analysis of various journals related to Hula Hoop dance and early childhood characters shows the meaning and relationship between Hula Hoop and early childhood characters based on content analysis.

\section{RESULT AND DISCUSSION}

The researchers used the Miles and Huberman analysis model based on data analysis, consisting of 3 stages: 1) Data Reduction, (2) Data Display, and 3) Verification and conclusion. The data reduction stage is the stage of selecting data related to the research topic. Relevant data were collected to analyze at a later stage. The researcher identified various research results relevant to character development in hula hoop dancing. The display stage is the second stage, so it displays relevant data from the form of character development identified from literature review sources. Each form of hula hoop development is classified based on the type of character development of hula hoop dancing. Display data can be seen in figure 1.
Figure 1. 13 Characters from dancing Hula Hoop

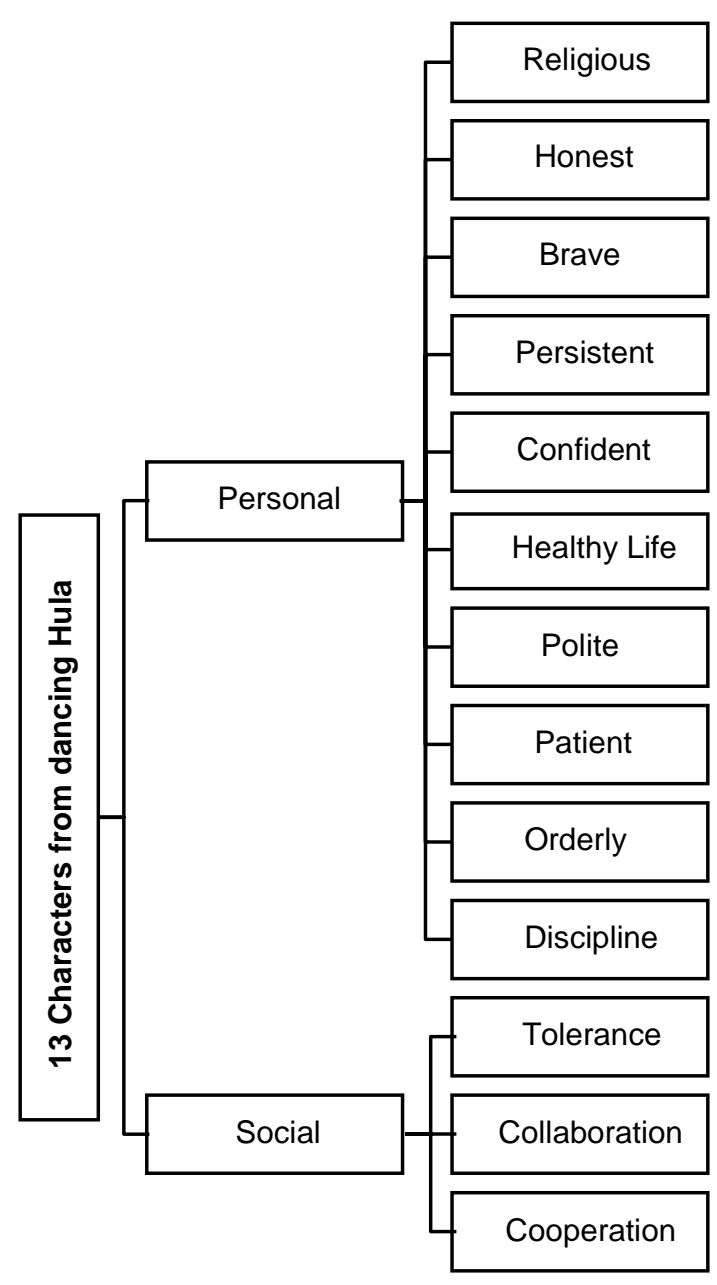

The next stage is the third stage, data verification and conclusion. Researchers analyzed the contents of each literature review that have been referenced. Data relevant to the topic is confirmed between one reference and another. After this process is done, the researchers can conclude the research. The research conclusion showed 13 children's characters who developed during dancing hula hoop.

People who are most confident with fundamental movement skills can participate in various recreational activities throughout their lives [7]. In connection with this study, children who are skilled in fundamental movement and children who are skilled and skilled at moving with Hula Hoop, of course, these children have high self-esteem and self-confidence. Besides, they are more willing to take risks when playing games on the school grounds with their friends. Another positive impact of children who have good necessary movement skills from using the Hula Hoop dance is maintaining 
an active and healthy lifestyle throughout life. The child's confidence will increase if the child experiences success. The successful experience of turning Hula Hoop in the stomach without falling makes the child's confidence increase.

[8] The essential of character development in schools and discussed support the theoretical basis and importance of the following useful character, for example, Attitudes, self-effectiveness, values, selfconcept, and interests. Thus, things related to this are essential to be developed in schools' stimulation programs to develop children's attitudes. When linked with a movement stimulation program, children's attitudes must also be a concern for teachers in planning and performing dance. Dancing hula hoop can be done by teachers continuously. Hula hoop dancing activities performed continuously can stimulate the character of the child. The hula hoop dance activity is useful so that the child is skilled and a child with character. The following is effective development: (1) Individuals; religious, honest, brave, persistent, confident, healthy life, polite, patient, orderly, and disciplined. (2) Social; tolerance, cooperation, and cooperation [3].

Religious are holy things, have high spiritual values. Habituation methods proved to be very useful in stimulating the religious attitudes of early childhood [6]. It is essential to improve religious attitudes in children as early as possible. Early childhood is a sensitive period in absorbing various positive things in the environment. [22]. This attitude exists in all references studied that can be seen when the children started the Hula Hoop dance activity, starting and ending with a prayer. The pray activity is done consistently, resulting in a religious attitude in thechild. An honest attitude can be seen in the development of the hula hoop dance when children tell their teacher the truth about how many rounds of Hula Hoop they have done. Besides that, being honest also means doing something with the agreed rules of the Hula Hoop Dance. The development of an honest attitude is reflected in the development of children's movements [9].

A bold attitude emerged when the Hula Hoop dance development was carried out by showing them how to play Hula Hoop without shame in front of many people. Children dare to show their ability to dance Hula Hoop. The development of a courageous attitude is related to the child's ability to dance Hula Hoop [10].

Persistence is one of the children's attitudes to try until they succeed in achieving their goals continuously. This attitude shows that the child has difficulty turning the Hula Hoop, who always falls. But with the continuous fall of Hula Hoop, children learn to think that when they try to keep trying to play Hula Hoop, they will be able to positively. Besides, children also learn to be patient, waiting for good results. [11] This motivation also came from teachers and other friends who were already skilled at playing Hula Hoop. Of course, persistence is one of the characters formed because of continuous motor development $[12,13]$.

Confidence arises when children begin to play the Hula Hoop skillfully. Children begin to believe in their ability to explore with Hula Hoop. Self-confidence is influenced by a brave attitude showing his ability to play the Hula Hoop [10, 14].

Children are taught that doing the Hula Hoop movement is suitable for their health, marked by their bodies' changes. Initially, the heart rate, the pulse in the neck beating faster, and the sweat released after the activity using the Hula Hoop. The activity makes children understand the positive impact on their bodies to build a healthy character $[10,12]$.

Polite attitude [14] is illustrated when the children finish using the Hula Hoop; they return it with thanks. The child is also orderly [18] and disciplined [19] when returning the Hula Hoop to its place.

Besides individual character development, Hula Hoop activities also develop social character in early childhood, including tolerance. This attitude of tolerance is awakened when the children dance the Hula Hoop together. Children tend to want to show their abilities. Still, when the teacher allows one of the children to exemplify the movement, the other child will reduce the sense of wanting to show his abilities by being tolerant by giving his friends opportunities [10]. Also, collaboration and cooperation can be awakened when children dance together. A friend who is skilled at playing Hula Hoop is seen helping to teach his unskilled friends to dance Hula Hoop together. The attitude of cooperation and cooperation is essential to build at an early age because it strengthens the relationship between one child and another [11] to adapt to their environment as adults quickly. It turns out that Hula Hoop dancing is not the only way to develop character. The research results are that there are so many movements and song development activities that can develop early childhood characters [16]. The results showed that Hula Hoop could also relieve stress and overcome excessive fatigue [20]. The results of other studies suggest that Hula Hoop can also increase flexibility [21]. Hula hoops can improve body fitness [15]. Other facts about Hula Hoops are obtained when someone does Hula Hoop activities for a time that suits their body's ability and proper movement. This 
physical fitness is felt by children after dancing the Hula Hoop, so that it supports the building of inner character, namely a healthy lifestyle. Hula Hoop dance is also essential because it is a form of movement and song activity that can stimulate early childhood characters.

Other studies on the same topic have shown different results. Studies have shown that the use of hula hoops only impacts children's motor skills [23]. The research is not wrong, but the research focus is different.

Researchers focus more on identifying the charactersbuilding in children during hula hoop dancing, while other studies focus on developing children's motor skills.

Other studies are also where the results are different.

Playing hula hoop can increase children's physical

fitness. The difference is not a problem because the purpose of the research is different. This research is divided into two sub-purposes. The first goal is to train endurance and movement agility. Both train flexibility. Although the same topic of research is hula hoop in early childhood, the purpose is different. Differences in research objectives make the results of his research do not support each other.

Different points of view on the topics discussed are the factors that distinguish the two studies [25].

According to preliminary research, Hula Hoop dance was developing affective aspects development of children in Kindergarten. Other research has shown that playing hula hoop can stimulate development aspects. Other studies have shown that early childhood gross motor skills and a positive effect can be improved by playing hula hoops. The three studies above can be a solution to research problems. State of the art is a hula hoop activity that developed children's character.

The implications of the research are directly based on a study. The implications of research play a role in strengthening research findings. This research implies that hula hoop dancing is needed to stimulate early childhood characters. Early childhood is the most crucial period in character formation. Based on the study findings, 13 characters of early childhood can be stimulated from dancing hula hoop.

\section{CONCLUSION}

The literature study of Hula Hoop Dance develops individual and social characters of early childhood. The personal characters include: religious, honest, courageous, persistent, confident, healthy, polite, patient, orderly, and disciplined. The social characters that can develop from Hula Hoop's activities include tolerance, collaboration, and cooperation.

\section{ACKNOWLEDGMENT}

This work was supported by the Institute for Research and community service, Sriwijaya University, and the Early Childhood Education Undergraduate Study Program in Teacher and Training Faculty, Sriwijaya University.

\section{REFERENCES}

[1] Sumarni S, Andika WD (2017) Hula Hoop Dance in Early Childhood ( Case Study in Bon Thorif Kindergarten, Palembang South Sumatera ). 58:429-435

[2] WFD Theron, "The Dynamics of an Elastic Hopping Hoop," vol. 7177, no. 02, 2002.

[3] R. Novitasari, M. Nasirun, and DD, "Improving Children's Gross Motor Skills through Playing with Hulahoop Media in Children of Group B Paud Al-Syafaqoh, Rejang Lebong Regency," J. Ilm. POTENCIA, vol. 4, no. 1, pp. 6-12, 2019, DOI: 10.33369 / jeep. 4.1.6-12..

[4] A. Baltac1, "Nitel Veri Analizinde MilesHuberman Modeli," Ahi Evran Üniversitesi Sos. Bilim. Enstitüsü Derg., vol. 3, no. 1, pp. 1-15, 2017, [Online]. Available: https://dergipark.org.tr/en/pub/aeusbed/issue/30 008/290583.M. Bengtsson, "How to plan and perform a qualitative study using content analysis," NursingPlus Open, vol. 2, pp. 8-14, 2016, DOI: 10.1016 / j.npls.2016.01.001.

[5] L. Sgier, "Qualitative Data Analysis University Program," pp. 1-7, 2014.

[6] Antara H, Pembiasaan M, Sikap D, Maldarisa OG, Hendrawijaya AT, Imsiyah N, et al. Religius Anak Usia Dini Di Paud Kelompok Bermain Mawar 02 Kabupaten Lumajang ( the Corellation Between a Methods of Habituation With a Religious Attitudes of Early Childhood At Paud Play Group Mawar 02 Lumajang ). 2017;7-9.

[7] Byrd-bredbenner C, Martin-biggers J, Alleman G, Worobey J, Hongu N, Quick V (2017) Promoting healthy home environments and lifestyles in families with preschool children HomeStyles, a randomized controlled trial. Contemp Clin Trials 1-13

[8] Hnatiuk J, Barnett L, Salmon J, Hesketh K (2018) Can child and family behaviors in the first year of life predict fundamental movement skill development at five years old? J Sci Med Sport 21:S14

[9] Gunadi DIP (2019) Peran Orang Tua dalam Optimalisasi Tumbuh Kembang Anak untuk Membangun Karakter Jujur. 34-47

[10] Iswantiningtyas V, Wulansari W (2018) 
Pentingnya Penilaian Pendidikan Karakter Anak Usia Dini. Proc ICECRS 1:197-204

[11] Supriyanti S, Suharto D (2015) Penciptaan Tari Manggala Kridha sebagai Media Pembentukan Karakter bagi Anak. J Urban Soc Arts 2:18-24

[12] HAPIDIN H, YENINA Y (2016)

Pengembangan Model Permainan Tradisional Dalam Membangun Karakter Anak Usia Dini. JPUD - J Pendidik Usia Dini 10:201-212

[13] Arisyanto P, Sundari RS, Untari MFA (2018) Pembelajaran Ekstrakurikuler Tari Untuk Penanaman Karakter Bagi Siswa SD Negeri Gayamsari 02 Semarang. J Pendidik dan Kaji Seni 3:1-13

[14] Andriani T (2012) Permainan Tradisional Dalam Membentuk Karakter Anak Usia Dini. J Sos Budaya 9:121-136

[15] Rohman U (2019) Hula hoop game: its use and implication for physical fitness. J Sport J Penelit Pembelajaran 5:249

[16] Novitasari R, Nasirun M, D. D (2019) Meningkatkan Kemampuan Motorik Kasar Anak Melalui Bermain Dengan Media Hulahoop Pada Anak Kelompok B Paud AlSyafaqoh Kabupaten Rejang Lebong. J Ilm POTENSIA 4:6-12

[17] Yulianti R (2016) Pembelajaran tari kreatif untuk meningkatkan pemahaman cinta lingkungan pada anak usia dini. J Pendidik dan Kaji Seni 1:29-42

[18] Yati P (2016) Pendidikan Karakter Anak Usia Dini Melalui Metode Pembelajaran Field Trip. Lentera XVIII:123-139

[19] Sutini A (2018) Pembelajaran Tari Bagi Anak Usia Dini. Cakrawala Dini J Pendidik Anak Usia Dini. https://doi.org/10.17509/cd.v3i2.10333

[20] Msn CS, Rn AV, Msn LJ (2014) Hoop Dancing to Prevent and Decrease Burnout and Compassion Fatigue. J Emerg Nurs 40:394-395

[21] Theron WFD (2002) T h e D y n a m I c s of an Elastic H o p p in g H o o p. 7177:

[22] Sudjarwati S, Fahyuni EF. Peran Literasi Moral Meningkatkan Karakter Religius Anak Usia Dini. Al-Tadzkiyyah J Pendidik Islam. 2020;10(2):219-29.

[23] Pendidikan J, Anak I, Dini U, Tarbiyah F, Ilmu DAN. Meningkatkan motorik kasar anak melalui bermain hulahoop pada tk permata bunda cubadak kabupaten tanah datar skripsi. 2018;

[24] Sudjarwati S, Fahyuni EF. Peran Literasi Moral Meningkatkan Karakter Religius Anak Usia Dini. Al-Tadzkiyyah J Pendidik Islam. 2020;10(2):219-29.

[25] Setiawan J. Tinjauan buku. J TULOS. 2018;16(2):207-27. 